\title{
Studies on acoustic comfort in a passive house
}

\author{
Catalin BAILESCU ${ }^{1}$, Tiberiu CATALINA ${ }^{1}$, and Vlad IORDACHE \\ ${ }^{1}$ Technical University of Civil Engineering, Faculty of Building Services, Bucharest, ROMANIA
}

\begin{abstract}
Acoustic comfort is a requirement of major importance during the design of houses. This study focused on the acoustic comfort parameter called sound pressure level. The value of this parameter is variable during operation of a particular building, depending on the type of absorbent material and them surface. The aim of this study is to determine the influence of the equipment of the technical space for a passive house. In this study was experimentally determined the value of noise for a Passive House in Romania using specialized equipment and software from Bruel \& Kjaer. With these equipment and software were simulated different functional parameters of heat recovery and circulation pump, and different ways of placing the house on various types of roads leading sound pressure level simultaneously for five rooms, result compared with rules imposed values for each type of room.
\end{abstract}

\section{Introduction}

The study of acoustic comfort is attracting interest growing for environmental quality assessment of a building. The effects produced by noise pollution or by an uncomfortable environment manifest themselves especially on health (psychological health disorder for domestic dwellings or houses).

The production of scientific publications is growing on the subject of acoustic comfort in the building [1] and despite the need for a consensus on definition and on the criteria of acoustic comfort [2], the Acoustic regulations of different European countries vary considerably in the objectives to be achieved in terms of descriptors, frequency ranges considered and levels [3]. The problem is not the object of a European consensus and the terms of comfort acoustics remain to be defined. The perception of the sound environment at home depends on the links between sources of noise (from public space, common areas and private space), acoustic performances of the constructive systems and other non-acoustic factors such as demographics, noise sensitivity, etc.

Acoustic comfort is a priority in top design, especially in green buildings, where the emphasis is on using as few resources as possible and creating healthy environments to care for occupants. However, studies by the Center for the Built Environment (CBE), University of California, Berkeley, show that occupants in green buildings are generally more dissatisfied with acoustic comfort than those in normal buildings. The reason for this deficiency seems to be that many design practices for posterior buildings are inconsistently contradicting the methods that acoustic professionals typically use to control noise, understanding speech, and reverberation.
In the European countries the limits of the noise level are require by noise assessment standard [4] and the regulations on noise exposure [5].

In Romania legal regulation for building acoustics [6] impose maximum noise level limits maximum considering the room's destination and the type of building.

Because in passive buildings it is also necessary to prepare the heating agent and to transport it to the heating equipment, the noise produced by this equipment was studied.

In this article we considered the noise analysis produced by the technical spaces of the Efden building, a passive building located in the courtyard of the Faculty of Engineering of Installations in Bucharest. It has also been verified that the Romanian rules are met in terms of meeting the acoustic comfort conditions.

Because road traffic noise is considered the main source of environmental and living loss in a metropolis, [7] much of previous studies on acoustic comfort has been focused on road, rail and air traffic [8],[9],[10]. In study like [11] it has been reported that in residential buildings an important source of acoustic discomfort is noise from a boiler plant.

In this article we have proposed that besides noise from the technical room witch is an important consideration in operation all buildings to analyze the influence of the noise level according to the street type on the interior acoustic comfort in a passive house in Romania.

\footnotetext{
* Corresponding author: tiberiu.catalina@gmail.com
} 


\section{Study case}

The analysed building is the concept around which a team of more than 50 students from 3 universities in Bucharest (future engineers, architects, communicators) have developed a prototype solar house for the urban environment.

Measurements were made on an experimental stand that consisted of a five-room set:

- Living Room: $18.60 \mathrm{~m} 2$;

- Kitchen \& Dinning: 21.10m2;

- Master Bedroom: 18.00 m2;

- Bedroom: $13.40 \mathrm{~m} 2$;

- Technical room: $7.40 \mathrm{~m} 2$;

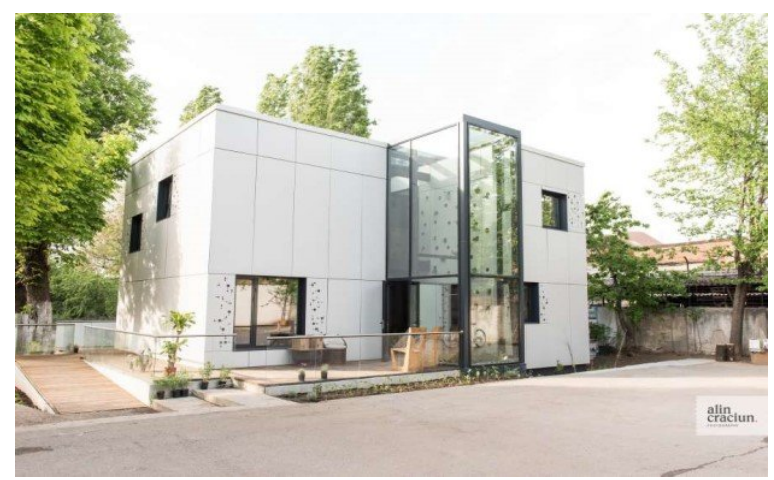

Fig. 1. EfdeN house on the outside

Using the Pulse Labshop ver 15.1.0 software, 15 experiments were performed for each of the 5 sources for 10 seconds, a total of 750 acoustic pressure levels. Thus, not all frequencies are perceived as being equally loud at the same sound pressure level, and when calculating overall environmental noise ratings it is necessary to consider sounds at some frequencies as more important than those at other frequencies. Detailed frequency analyses are performed with standard sets of octave or $1 / 3$ octave bandwidth filters.

This device with precision class 1 has recorded values that were saved by the txt file software imported into Excel and subsequently processed to obtain the sound pressure levels in $\mathrm{dB}$.

Table 1. Studied cases

\begin{tabular}{|c|c|c|c|}
\hline Case & $\begin{array}{c}\text { Stage of } \\
\text { circulating pump }\end{array}$ & $\begin{array}{c}\text { Fan speed in the } \\
\text { heat recovery }\end{array}$ & $\begin{array}{c}\text { Outside } \\
\text { Traffic }\end{array}$ \\
\hline 1 & 1 & MAX & NO \\
\hline 2 & 4 & MAX & NO \\
\hline 3 & 7 & MAX & NO \\
\hline 4 & 1 & AVERAGE & NO \\
\hline 5 & 4 & AVERAGE & NO \\
\hline 6 & 7 & AVERAGE & NO \\
\hline 7 & 7 & - & NO \\
\hline 8 & 7 & - & IV \\
\hline 9 & 7 & - & III \\
\hline 10 & 7 & - & II \\
\hline 11 & 7 & - & I \\
\hline 12 & 7 & - & IV \\
\hline 13 & 7 & - & III \\
\hline 14 & 7 & - & II \\
\hline 15 & 7 & - & I \\
\hline
\end{tabular}

Fig. 1 shows the positions of the equipment used for acoustic measurements. Sound level meter multi purpose input module and laptop were placed in the living room, where the microphone 4 is positioned, and in the kitchen is placed the microphone number 3.

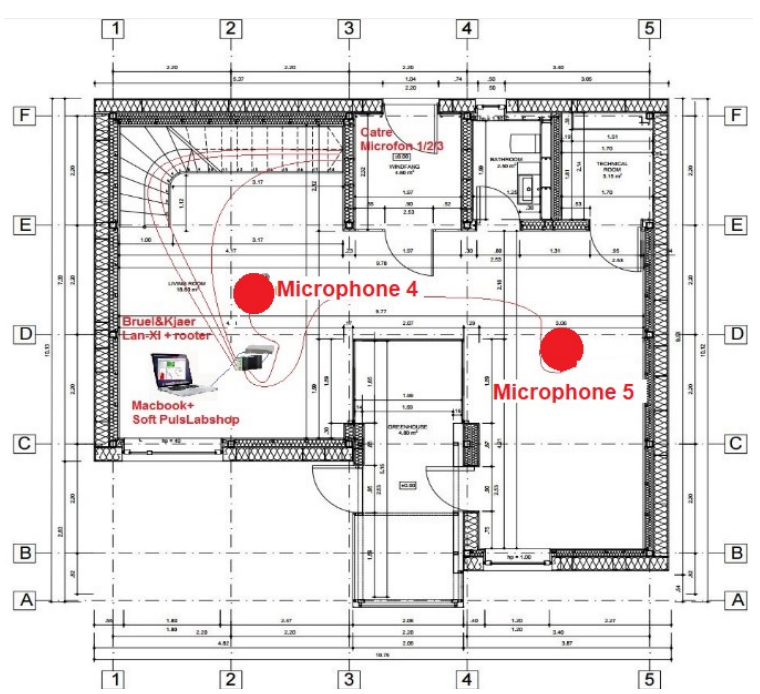

Fig. 2. Equipment used in the experiment on the ground floor of the EfdeN house

In the next figure with red are the microphones placed in the bedrooms and in the technical space.

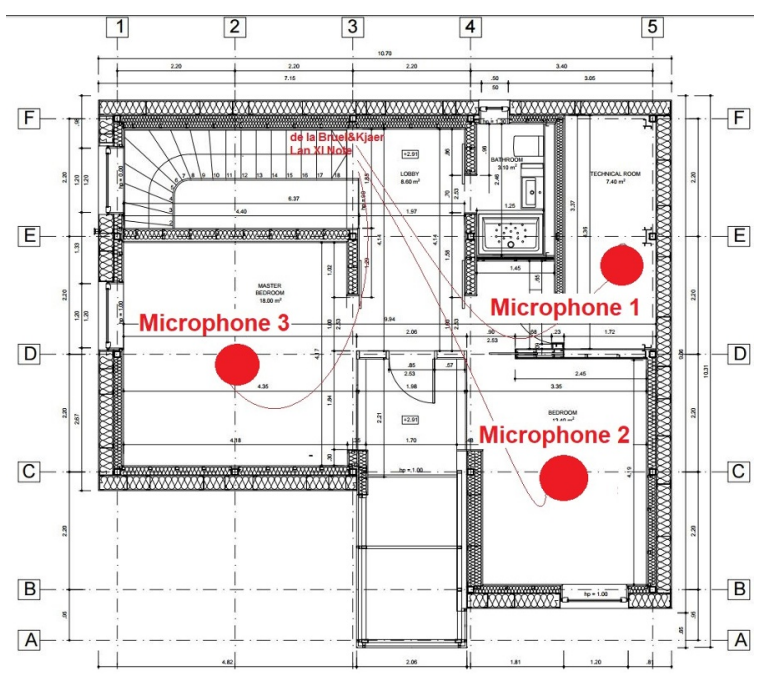

Fig. 3. Equipment used in the experiment on the first floor of the EfdeN house

\subsection{Data analysis}

Because the noise is variable over time, instantaneous measurement of this noise level is not characteristic of that that acoustic parameter. The classic method is to measure the value of a parameter that varies over time and determine the average of these values.

Equivalent noise level (LAeq) / linear weighting: through LAeq weighted to seek the evaluation of a sound at a position in space and on duration $\tau$, through a single value of average acoustic energy; 


$$
L p_{\text {eeh }}=10 \cdot \log _{10}\left[\Sigma_{i}\left(\frac{\Delta t i}{\tau} \cdot 10^{\frac{L p_{i}}{10}}\right)\right]
$$

We have included within the bracket of the formula below all 11 values with equal weights between them and equal to $1 / 11$. Thus, through this method, resolving can be done more precisely, but the working time is higher, so it is preferable to solve this problem when using a computer to automate this calculation.

The noise level measuring instruments used in the experiment evaluate the acoustic intensity by measuring the pressure. The transition from the real-to-weighted noise level is achieved by adding above the actual noise level the value of the reading by the weighting curve, the different value depending on the frequency, thus simulating the non-linearity of the human audible range, so it is possible to finally simulate the sensation sound.

Table 2. Noise level measured in the Technical Room

\begin{tabular}{|l|c|c|c|c|c|c|}
\hline Frequency & $\begin{array}{c}125 \\
\mathrm{~Hz}\end{array}$ & $\begin{array}{c}250 \\
\mathrm{~Hz}\end{array}$ & $\begin{array}{c}500 \\
\mathrm{~Hz}\end{array}$ & $\begin{array}{c}1000 \\
\mathrm{~Hz}\end{array}$ & $\begin{array}{c}2000 \\
\mathrm{~Hz}\end{array}$ & $\begin{array}{c}4000 \\
\mathrm{~Hz}\end{array}$ \\
\hline $\begin{array}{l}\text { L 1 Tehnical } \\
\text { room[dB] }\end{array}$ & 37.17 & 38.82 & 42.62 & 41.23 & 38.01 & 39.20 \\
\hline $\begin{array}{l}\text { Weight A } \\
\text { curve, } \\
\Delta \mathrm{Lp}[\mathrm{dB}]\end{array}$ & -16.1 & -8.6 & -3.2 & 0 & 1.2 & 1 \\
\hline $\begin{array}{l}\mathrm{Lp} \text { 1 Tehnical } \\
\text { room[dBA] }\end{array}$ & 21.07 & 30.22 & 39.42 & 41.23 & 39.21 & 40.20 \\
\hline
\end{tabular}

After weighing, it is noticed that the level of noise heard by the human is considerably diminished for the $125 \mathrm{~Hz}$ and $250 \mathrm{~Hz}$ frequencies compared to the real and amplified noise for the $2000 \mathrm{~Hz}$ and $4000 \mathrm{~Hz}$ frequencies.

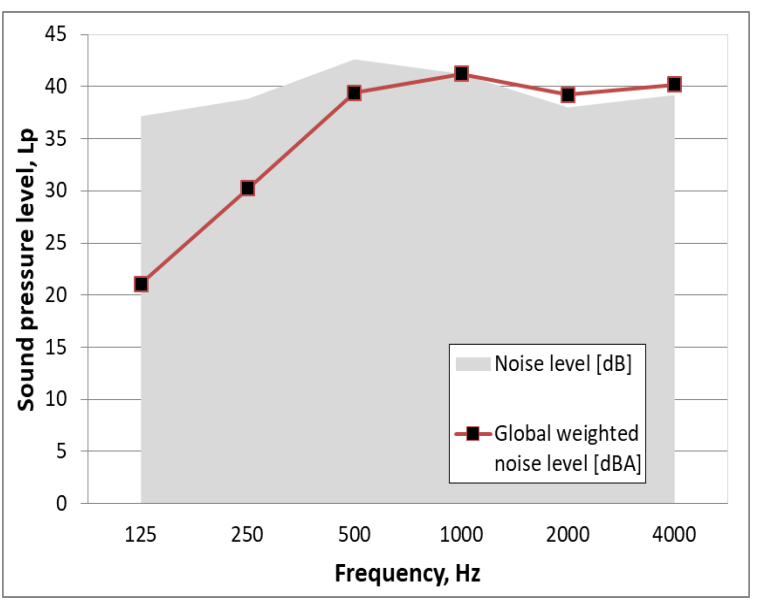

Fig. 4. Variation of sound pressure level on the inside

\subsection{Experimental study no.1}

In the first part of the study of the experimental data, it was desired to analyze the degree of sound insulation of the partition wall between Bedroom and the Technical room. The partition wall has the dimensions of
$1.72 \times 2.91 \mathrm{~m}$, so $5 \mathrm{~m} 2$, is made of simple plasterboard wall with a thickness of $9.5 \mathrm{~mm}$. The construction phase of this building is not completed, this wall being plated with sound absorbing material.

In the Technical room there is a heat recovery and a circulation pump that produces local noise, while Bedroom is a silent room. In both rooms were placed microphones placed in the center of the room so that the sound pressure levels of the two rooms could be measured simultaneously.

This first experimental study consisted of two experiments, which varied how the equipment works in the technical space. In the first experiment a normal operation of the heat recovery and circulation pump was simulated. The sound was propagated from the transmitter - Technical room to the receiver - Bedroom, the noise level of the receiver (Table 4) being lower than that of the emitter. The measured values of the two noise levels were read through the Bruel \& Kjaer Lan XI digital reader, reading with a $0.1 \mathrm{~dB}$ error margin, due to the approximations made by the LabShop ver 15 Software.

For the second experiment, a maximum load operation of the Technical Room equipment was simulated. There were phenomena like the first experiment, but of different values.

Table 3. Simultaneous measurements of noise level in Technical room and Bedroom

\begin{tabular}{|l|c|c|c|c|c|c|}
\hline Frequency & $\begin{array}{c}125 \\
\mathrm{~Hz}\end{array}$ & $\begin{array}{c}250 \\
\mathrm{~Hz}\end{array}$ & $\begin{array}{c}500 \\
\mathrm{~Hz}\end{array}$ & $\begin{array}{c}1000 \\
\mathrm{~Hz}\end{array}$ & $\begin{array}{c}2000 \\
\mathrm{~Hz}\end{array}$ & $\begin{array}{c}4000 \\
\mathrm{~Hz}\end{array}$ \\
\hline $\begin{array}{l}\text { L 1 Tehnical } \\
\text { room[dB] }\end{array}$ & 20.30 & 20.26 & 33.2 & 29.48 & 28.66 & 27.08 \\
\hline $\begin{array}{l}\text { L 1 Bedroom } \\
{[\mathrm{dB}]}\end{array}$ & 15.13 & 20.13 & 27.13 & 14.39 & 16.26 & 28.68 \\
\hline $\begin{array}{l}\text { L 2 Tehnical } \\
\text { room [dB] }\end{array}$ & 37.18 & 38.96 & 42.62 & 41.23 & 38.01 & 39.20 \\
\hline $\begin{array}{l}\text { L2 Bedroom } \\
{[\mathrm{dB}]}\end{array}$ & 30.62 & 30.75 & 33.87 & 33.49 & 35.78 & 39.01 \\
\hline
\end{tabular}

The sound insulation of the bedroom that separates Bedroom from the Technical Room is determined by two parameters: the gross insulation $\mathrm{D}_{\mathrm{b}}[\mathrm{dB}]$ and the acoustic attenuation index $\mathrm{R}[\mathrm{dB}]$. First we determined the real values of these two parameters characteristic of the partition wall, based on the experiments performed.

Thus, the first parameter, the gross isolation, represents the pressure level difference between the emitter's location and the receptor's (equation 1). It will be calculated for the $1000 \mathrm{~Hz}$ frequency.

For Stage 4 of the circulation pump, maximum fan speed of the heat recovery and without traffic to the outside the gross insulation $\mathrm{D}_{\mathrm{b}}[\mathrm{dB}]$ is:

$\mathrm{D}_{\mathrm{b}}=\mathrm{L} 1-\mathrm{L} 2=49.48-34.39=15.08 \mathrm{~dB}$

For Stage 7 of the circulation pump, maximum fan speed of the heat recovery and without traffic to the outside The gross insulation $\mathrm{D}_{\mathrm{b}}[\mathrm{dB}]$ is:

$\mathrm{D}_{\mathrm{b}}=\mathrm{L} 1-\mathrm{L} 2=61.23-53.49=7.74 \mathrm{~dB}$ 
The experimentally obtained raw insulation value spectrum is graphically represented in Figure 6. On the second parameter, the sound attenuation index, we calculate it according to the raw isolation, the volume of the receiver locus $\mathrm{V}=40.82 \mathrm{~m} 3$, the measured reverberation time of the same local $\operatorname{Tr} 12[\mathrm{~s}]$ and the total surface of the partition wall $\mathrm{S}=5 \mathrm{~m} 2$. This calculation is exemplified for the $1000 \mathrm{~Hz}$ frequency.

$$
R=D_{b}+10 \log _{10}\left(\frac{S}{\frac{0.16 * V}{T_{r}}}\right)
$$

For Stage 4 of circulation pump, maximum fan speed of heat recovery and without traffic to the outside, the sound attenuation index $\mathrm{R}[\mathrm{dB}]$ is:

$$
\begin{aligned}
& R=15.09+10 \log _{12}\left(\frac{5}{\frac{5.15 \cdot d 0.35}{14}}\right) \\
& \mathrm{R}=15.38 \mathrm{~dB}
\end{aligned}
$$

For Stage 7 of the circulation pump, maximum fan speed in the heat recovery and without traffic to the outside, the sound attenuation index $\mathrm{R}[\mathrm{dB}]$ is:

$$
\begin{aligned}
& R=7.74+10 \log _{10}\left(\frac{5}{\frac{0.16 \cdot 40.80}{1.4}}\right) \\
& \mathrm{R}=8.04 \mathrm{~dB}
\end{aligned}
$$

The entire spectrum of the acoustic attenuation index is graphically represented in Figure 6 and Figure 7, and all values determined experimentally for the two acoustic parameters are shown in Table 4.

Table 4. Acoustic parameters determined experimentally

\begin{tabular}{|l|c|c|c|c|c|c|}
\hline Frequency & $\begin{array}{c}125 \\
\mathrm{~Hz}\end{array}$ & $\begin{array}{c}250 \\
\mathrm{~Hz}\end{array}$ & $\begin{array}{c}500 \\
\mathrm{~Hz}\end{array}$ & $\begin{array}{c}1000 \\
\mathrm{~Hz}\end{array}$ & $\begin{array}{c}2000 \\
\mathrm{~Hz}\end{array}$ & $\begin{array}{c}4000 \\
\mathrm{~Hz}\end{array}$ \\
\hline $\mathrm{Db}_{1}[\mathrm{~dB}]$ & 5.18 & 0.13 & 16.05 & 15.08 & 12.40 & 8.44 \\
\hline $\mathrm{R}_{1}[\mathrm{~dB}]$ & 5.48 & 0.43 & 16.35 & 15.38 & 12.70 & 8.74 \\
\hline $\left.\mathrm{Db}_{2}[\mathrm{~dB}]\right]$ & 6.55 & 8.07 & 8.76 & 7.74 & 2.24 & 0.19 \\
\hline $\mathrm{R}_{2}[\mathrm{~dB}]$ & 6.85 & 8.37 & 9.05 & 8.04 & 2.54 & 0.49 \\
\hline
\end{tabular}

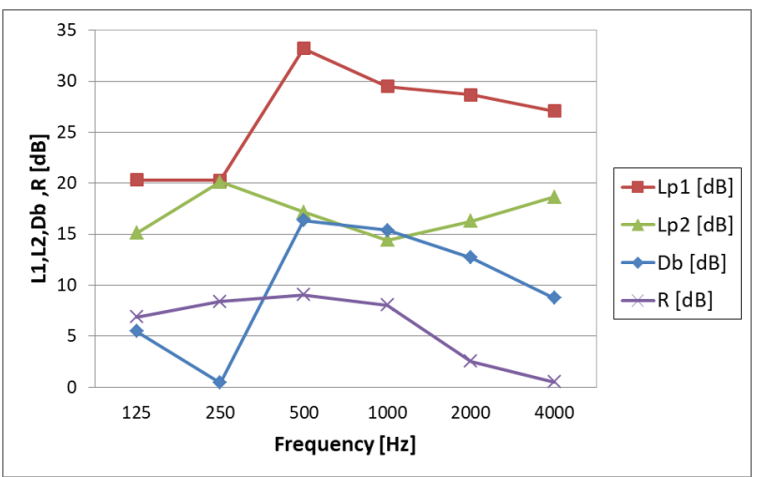

Fig. 5. Experimental values of the sound insulation indices of the wall for Situation1

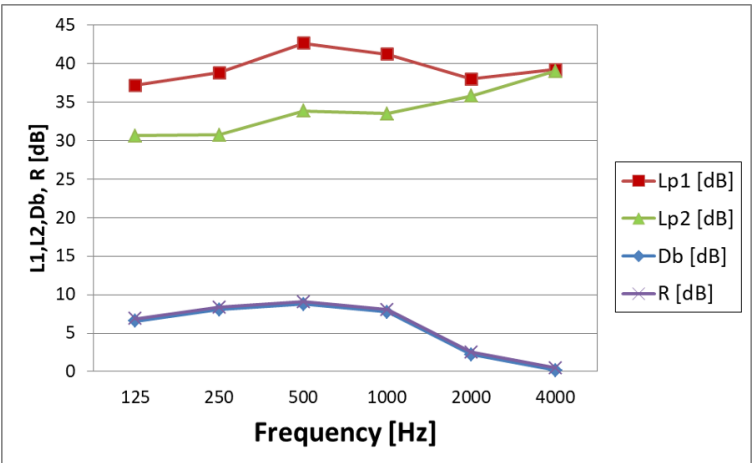

Fig. 6. Experimental values of the sound insulation indices of the wall for Situation2

For the two operating scenarios of the equipment in the technical space, we notice that the acoustic isolation between this two rooms due to the partition wall is 15.09 for the simulation of operation no. 1, and 7.75 for operating simulation no. 2 . and the sound attenuation index has higher values 16.71 . respectively 9.37 , keeping the same upward trend in relation to the frequency up to $1000 \mathrm{~Hz}$. This pro-rising trend of the two indices is however reversed for frequencies between $1000 \mathrm{~Hz}$ and $4000 \mathrm{~Hz}$. This result is due to the different behavior of the same wall at different frequencies.

\subsection{Experimental study $\mathrm{nr} .2$}

This chapter will describe the experimental airborne noise study conducted in the EfdeN house. We will analyze the transfer of the sound wave from the technical spaces to the other rooms and from the 1 st floor to the ground floor of the building, and then all the measured values of the noise level in all 5 rooms.

The figures below will show the noise levels for the operating scenario of the equipment in the technical area that created the most noise. Then a comparison was made between the noise levels recorded in the 5 rooms of the building and the permissible noise limits for each type of destination.

Also, to analyze how indoor acoustic comfort is influenced by street noise, external noise was simulated in accordance with the values indicated in STAS $6161 /$ $1-79$.

Table 5. The admissible values of the external noise level on the streets, measured at the sidewalk edge of the sidewalk, are determined according to the technical category of the streets.

The permissible sound levels of the external noise on the streets measured at the sidewalk edge of the sidewalk are determined the technical category of the streets

\begin{tabular}{|l|l|c|c|c}
\hline Crt. & $\begin{array}{l}\text { Type of street } \\
\text { (according to } \\
\text { STAS 10144 / } \\
1-80 \text { ) }\end{array}$ & $\begin{array}{c}\text { Equivalent } \\
\text { noise level } \\
\text { dB(A) }\end{array}$ & $\begin{array}{c}\text { CZ } \\
\text { Curve } \\
\mathrm{dB}\end{array}$ & $\begin{array}{c}\text { Peak } \\
\text { noise } \\
\text { level } \\
\mathrm{dB}(\mathrm{A})\end{array}$ \\
\hline 1 & $\begin{array}{l}\text { Category IV, } \\
\text { serving local } \\
\text { street }\end{array}$ & 60 & 35 & 70 \\
\hline 2 & $\begin{array}{l}\text { Category III, } \\
\text { collection street }\end{array}$ & 65 & 60 & 75 \\
\hline 3 & Category II, & 70 & 65 & 80 \\
\hline
\end{tabular}




\begin{tabular}{|l|l|c|c|c}
\hline & $\begin{array}{l}\text { connection } \\
\text { street }\end{array}$ & & & \\
\hline 4 & $\begin{array}{l}\text { Category I, bus } \\
\text { street }\end{array}$ & $75 \ldots .85$ & $70 \ldots$. & $85 \ldots .9$ \\
& & 80 & 5 \\
\hline
\end{tabular}

To simulate the noise produced by the street categories described above, a white noise source of the Omni power 4292L type was used on the main facade of the building. Using the portable type 2270 sound meter, noise levels were measured at 2 meters from the facade of the building.

Table 6. Experimental values of the acoustic pressure level for the 5 microphones in the most disadvantageous situation of the functioning of the equipment in the technical space

\begin{tabular}{|l|c|c|c|c|c|c|}
\hline Frequency & $\begin{array}{c}125 \\
\mathrm{~Hz}\end{array}$ & $\begin{array}{c}250 \\
\mathrm{~Hz}\end{array}$ & $\begin{array}{c}500 \\
\mathrm{~Hz}\end{array}$ & $\begin{array}{c}1000 \\
\mathrm{~Hz}\end{array}$ & $\begin{array}{c}2000 \\
\mathrm{~Hz}\end{array}$ & $\begin{array}{c}4000 \\
\mathrm{~Hz}\end{array}$ \\
\hline $\begin{array}{l}\text { L1 Tehnical } \\
\text { room[dB] }\end{array}$ & 37.17 & 38.82 & 42.62 & 41.23 & 38.01 & 39.20 \\
\hline $\begin{array}{l}\text { L2 Bedroom1 } \\
{[\mathrm{dB}]}\end{array}$ & 30.62 & 30.74 & 33.87 & 33.49 & 35.77 & 39.01 \\
\hline $\begin{array}{l}\mathrm{L}_{3} \text { Bedroom2 } \\
{[\mathrm{dB}]}\end{array}$ & 10.82 & 10.81 & 16.19 & 14.40 & 16.12 & 19.46 \\
\hline $\begin{array}{l}\text { L4 Living } \\
\text { Room }[\mathrm{dB}]\end{array}$ & 10.42 & 10.28 & 12.94 & 12.48 & 15.31 & 18.15 \\
\hline $\begin{array}{l}\text { L 5 Kitchen } \\
\text { and Dinning } \\
{[\mathrm{dB}]}\end{array}$ & 11.71 & 10.56 & 12.88 & 14.35 & 16.76 & 19.68 \\
\hline
\end{tabular}

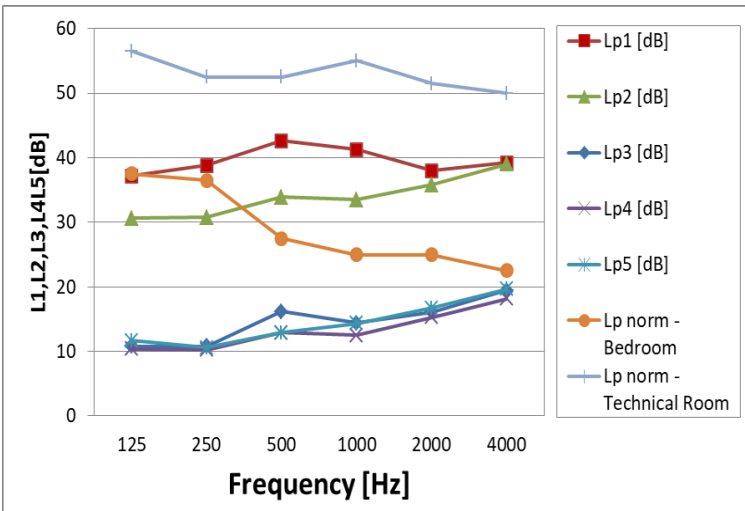

Fig. 7. The noise level for the 5 microphones and the regulations imposed by CZ30 STAS 6156/86

It is noted that for the most disadvantageous situation, created by a functioning at the maximum parameters of the equipment in the technical space, the acoustic pressure level fulfills the conditions imposed by STAS 6156/86, for all rooms except the bedroom located near the technical space, where due to lack the acoustic insulation of the wall separating the two rooms, the noise level exceeds the norm curve for the frequencies of 500, 1000,2000 and $4000 \mathrm{~Hz}$. In the following we will also analyze how street noise influences the noise inside the house.

Table 7. Experimental measurements of the sound pressure level recorded with the 5 microphones for Category IV Serving local Street

\begin{tabular}{|l|c|c|c|c|c|c|}
\hline Frequency & 125 & 250 & 500 & 1000 & 2000 & 4000 \\
\hline
\end{tabular}

\begin{tabular}{|l|c|c|c|c|c|c|}
\hline & $\mathrm{Hz}$ & $\mathrm{Hz}$ & $\mathrm{Hz}$ & $\mathrm{Hz}$ & $\mathrm{Hz}$ & $\mathrm{Hz}$ \\
\hline $\begin{array}{l}\text { L1 Tehnical } \\
\text { room[dB] }\end{array}$ & 38.78 & 39.78 & 52.06 & 38.53 & 36.75 & 39.25 \\
\hline $\begin{array}{l}\mathrm{L}_{2} \text { Bedroom1 } \\
\text { [dB] }\end{array}$ & 50.82 & 51.93 & 32.70 & 34.19 & 36.29 & 38.87 \\
\hline $\begin{array}{l}\text { L3 Bedroom2 } \\
{[\mathrm{dB}]}\end{array}$ & 31.53 & 23.41 & 16.78 & 21.36 & 18.06 & 39.78 \\
\hline $\begin{array}{l}\text { L4 Living } \\
\text { Room [dB] }\end{array}$ & 35.09 & 33.39 & 34.27 & 34.79 & 36.24 & 37.96 \\
\hline $\begin{array}{l}\text { L 5 Kitchen } \\
\text { and Dinning } \\
\text { [dB] }\end{array}$ & 34.11 & 34.11 & 33.77 & 35.38 & 37.16 & 39.70 \\
\hline
\end{tabular}

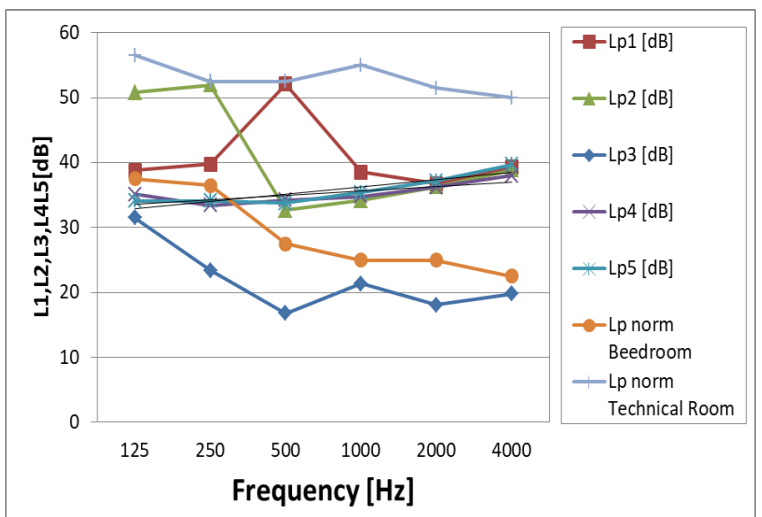

Fig. 8. The noise level recorded with the 5 microphones and the regulations imposed by CZ30 STAS 6156/86 for Category IV Serving local Street

From the above graph it can be seen that for the location of the house with the main façade towards a Category IV street, for the most disadvantageous functioning of the equipment in the technical space, the acoustic pressure level fulfills the conditions imposed by STAS $6156 / 86$ for the master bedroom technical space, the other rooms exceeding the requirements of the norms.

Table 8. Experimental measurements of the sound pressure level recorded with the 5 microphones for Category III Collection Street

\begin{tabular}{|l|c|c|c|c|c|c|}
\hline Frequency & $\begin{array}{c}125 \\
\mathrm{~Hz}\end{array}$ & $\begin{array}{c}250 \\
\mathrm{~Hz}\end{array}$ & $\begin{array}{c}500 \\
\mathrm{~Hz}\end{array}$ & $\begin{array}{c}1000 \\
\mathrm{~Hz}\end{array}$ & $\begin{array}{c}2000 \\
\mathrm{~Hz}\end{array}$ & $\begin{array}{c}4000 \\
\mathrm{~Hz}\end{array}$ \\
\hline $\begin{array}{l}\mathrm{L}_{1} \text { Tehnical } \\
\text { room[dB] }\end{array}$ & 59.29 & 59.02 & 72.25 & 59.06 & 57.14 & 59.11 \\
\hline $\begin{array}{l}\mathrm{L}_{2} \text { Bedroom1 } \\
{[\mathrm{dB}]}\end{array}$ & 53.81 & 58.17 & 56.93 & 59.19 & 57.60 & 59.00 \\
\hline $\begin{array}{l}\mathrm{L} \text { 3 Bedroom2 } \\
{[\mathrm{dB}]}\end{array}$ & 56.53 & 51.96 & 63.25 & 70.62 & 63.31 & 60.97 \\
\hline $\begin{array}{l}\mathrm{L}_{4} \text { Living } \\
\text { Room }[\mathrm{dB}]\end{array}$ & 63.76 & 60.02 & 57.77 & 59.01 & 58.58 & 58.42 \\
\hline $\begin{array}{l}\mathrm{L} 5 \text { Kitchen } \\
\text { and Dinning } \\
{[\mathrm{dB}]}\end{array}$ & 63.91 & 60.16 & 56.66 & 59.38 & 59.30 & 60.01 \\
\hline
\end{tabular}




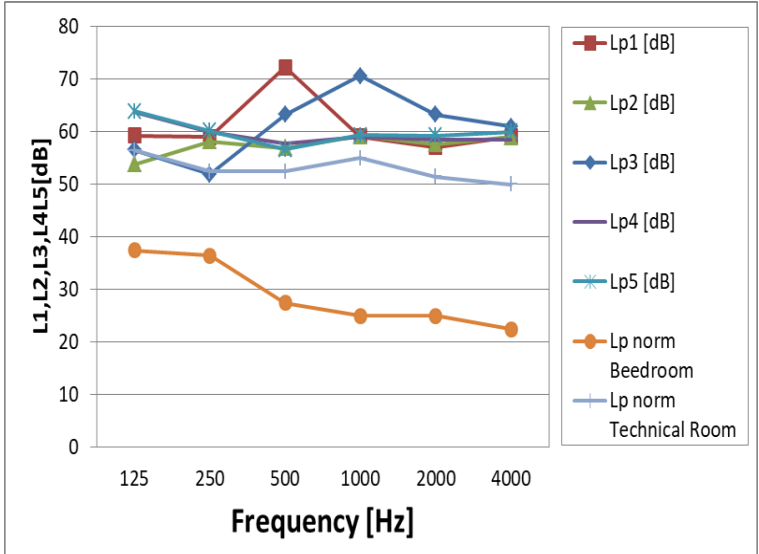

Fig. 9. The noise level recorded with the 5 microphones and the regulations imposed by CZ30 STAS 6156/86 for Category III Collection Street.

Figure 9 shows that for the location of the house with the main facade towards a Category III street and the most disadvantageous functioning of the equipment in the technical space, the acoustic pressure level does not meet the conditions imposed by STAS 6156/86 for any of the rooms.

Table 9. Experimental measurements of the acoustic pressure level for the 5 microphones for the Category II Connection Street

\begin{tabular}{|l|c|c|c|c|c|c|}
\hline Frequency & $\begin{array}{c}125 \\
\mathrm{~Hz}\end{array}$ & $\begin{array}{c}250 \\
\mathrm{~Hz}\end{array}$ & $\begin{array}{c}500 \\
\mathrm{~Hz}\end{array}$ & $\begin{array}{c}1000 \\
\mathrm{~Hz}\end{array}$ & $\begin{array}{c}2000 \\
\mathrm{~Hz}\end{array}$ & $\begin{array}{c}4000 \\
\mathrm{~Hz}\end{array}$ \\
\hline $\begin{array}{l}\text { L1 Tehnical } \\
\text { room[dB] }\end{array}$ & 59.33 & 59.88 & 72.47 & 59.35 & 57.68 & 59.31 \\
\hline $\begin{array}{l}\text { L2 Bedroom1 } \\
{[\mathrm{dB}]}\end{array}$ & 55.41 & 61.21 & 59.45 & 62.29 & 58.91 & 58.87 \\
\hline $\begin{array}{l}\text { L3 Bedroom2 } \\
{[\mathrm{dB}]}\end{array}$ & 57.29 & 73.98 & 66.83 & 73.36 & 66.16 & 61.94 \\
\hline $\begin{array}{l}\text { L4 Living } \\
\text { Room [dB] }\end{array}$ & 69.89 & 63.36 & 61.11 & 64.27 & 62.86 & 58.81 \\
\hline $\begin{array}{l}\text { L 5 Kitchen } \\
\text { and Dinning } \\
{[\mathrm{dB}]}\end{array}$ & 66.41 & 62.77 & 60.36 & 62.84 & 60.70 & 60.12 \\
\hline
\end{tabular}

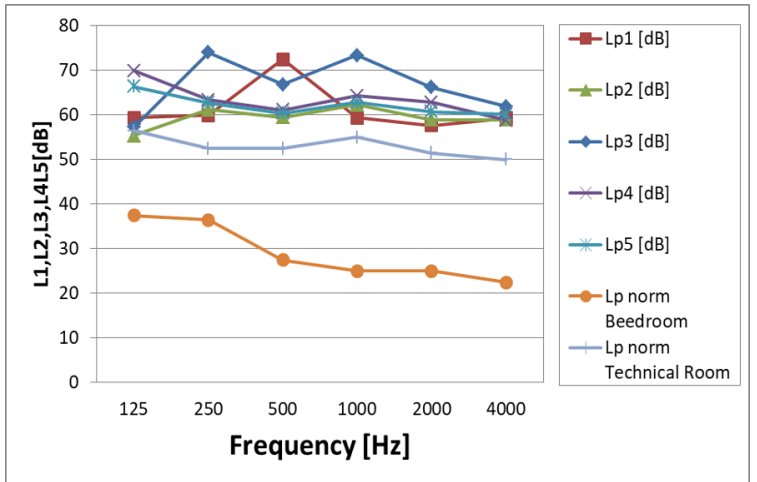

Fig. 10. The noise level recorded with the 5 microphones and the regulations imposed by CZ30 STAS 6156/86 for Category II Connection Street
Table 10. Experimental measurements of the acoustic pressure level for the 5 microphones for the Category I Bus Street

\begin{tabular}{|l|c|c|c|c|c|c|}
\hline Frequency & $\begin{array}{c}125 \\
\mathrm{~Hz}\end{array}$ & $\begin{array}{c}250 \\
\mathrm{~Hz}\end{array}$ & $\begin{array}{c}500 \\
\mathrm{~Hz}\end{array}$ & $\begin{array}{c}1000 \\
\mathrm{~Hz}\end{array}$ & $\begin{array}{c}2000 \\
\mathrm{~Hz}\end{array}$ & $\begin{array}{c}4000 \\
\mathrm{~Hz}\end{array}$ \\
\hline $\begin{array}{l}\mathrm{L}_{1} \text { Tehnical } \\
\text { room[dB] }\end{array}$ & 59.38 & 60.74 & 72.69 & 59.65 & 58.23 & 59.52 \\
\hline $\begin{array}{l}\mathrm{L}_{2} \text { Bedroom1 } \\
{[\mathrm{dB}]}\end{array}$ & 57.00 & 64.26 & 61.96 & 65.43 & 60.21 & 58.87 \\
\hline $\begin{array}{l}\mathrm{L}_{3} \text { Bedroom2 } \\
{[\mathrm{dB}]}\end{array}$ & 58.02 & 96 & 70.40 & 76.09 & 69.02 & 62.90 \\
\hline $\begin{array}{l}\text { L4 Living } \\
\text { Room }[\mathrm{dB}]\end{array}$ & 76.02 & 66.69 & 64.46 & 69.52 & 67.14 & 59.21 \\
\hline $\begin{array}{l}\text { L } 5 \text { Kitchen } \\
\text { and Dinning } \\
{[\mathrm{dB}]}\end{array}$ & 68.90 & 65.38 & 64.07 & 66.30 & 62.10 & 60.23 \\
\hline
\end{tabular}

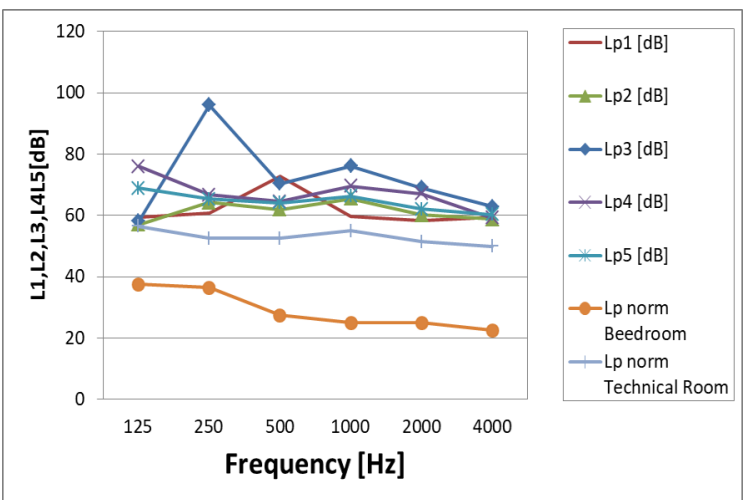

Fig. 11. The noise level recorded with the 5 microphones and the regulations imposed by CZ30 STAS 6156/86 for Category I Bus Street

From the two figures above it can be seen that for the location of the house with the main facade towards a Category I and II street, in the situation of the most disadvantageous functioning of the equipment in the technical space, the acoustic pressure level does not meet the conditions imposed by STAS 6156/86, for any of the rooms.

In the following, a comparison was made between the noise levels for Bedroom and Technical room in the normal operating situation of the equipment in the technical space, when the heat recovery and circulation pump works at maximum parameters, but also when the house is located on a street I and IV.

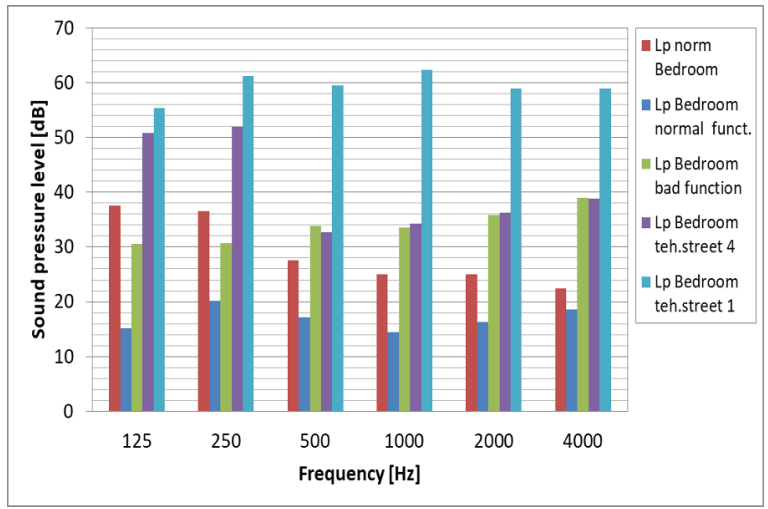


Fig. 12. The noise level for the Bedroom and the regulations imposed by rules for the 4 cases

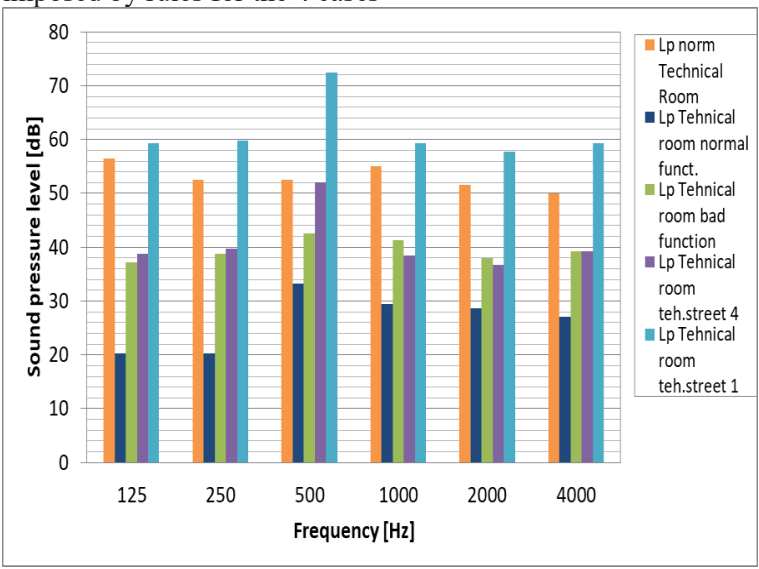

Fig. 13. The noise level for the Technical Room and the regulations imposed by rules for the 4 cases

From the two graphs above, it turns out that the minimum values required by the norm are fulfilled in the bedroom only by a normal operation of the equipment in the technical space. If these equipment works at maximum parameters, the requirements imposed by norms are fulfilled only for 125 and $250 \mathrm{~Hz}$ frequencies.

If the house is located on a traffic street, the limits of the noise level imposed by the rules will no longer be met. In the technical space, the noise levels indicated in the norms for this type of room are respected in all situations, except when the house is located on a Type 1 Street.

\section{Conclusions}

After achieving the experiment on EfdeN House it was found that the acoustic pressure level complies with the Romanian norms throughout the house for a normal functioning, but also for a maximum operating performance of the heat recovery and circulation pump, except for the bedroom near the technical space where the people in this room are faced with a high level of acoustic pressure that can be a stress factor for occupants.

Instead, if this passive house is located with the main facade towards a Category I and II street, in the most disadvantageous functioning of the equipment in the technical space, the acoustic pressure level does not meet the conditions imposed by STAS 6156/86 for none from the rooms.

The purpose of this paper was to carry out an experiment on one of the essential parameters of acoustic comfort the noise level, in a passive house in Romania and the comparison of the real situation with hypothetical situations of location of the house on the four types of streets described in STAS 6161 / 1-79.

The composition of the method followed for the work was as follows:

- room analysis: location, pictures, dimensions, acoustic walls, surfaces, volume

- learning equipment
- importing data;

- data processing;

- calculating the equivalent noise level

- acoustic weighting

- experimental studies

By synthesizing the theoretical studies, the following conclusions were reached:

1. After the visual inspection, certain areas where acoustic measurement was required were identified.

2. Using the Romanian norms we identified the acoustic conditions, respectively the level of sound pressure required for the destination of these rooms

3. The operation of the equipment in the technical space may affect the acoustic comfort of certain rooms;

4. The only solution in which the acoustic comfort meets the requirements of the norm is when the heat recovery and the circulation pump function at normal parameters

\section{Bibliography}

1. Al horr Y., Arif M., Katafygiotou M., Mazroe A., Kaushik A. et Elsarrag E. (2016), Impact of indoor environmental quality on occupant well-being and comfort: A review of the literature, Int Jour of Sustainable Built Environment, Vol. 5, p. 1-11, 2016

2. Cost Action TU901 (2011), Towards a common framework in building acoustics, Cost Office 2011

3. Rasmussen B. (2010), Sound classification schemes in Europe-quality classes intended for renovated housing. COST Action TU701, May 2010

4. International Organization for Standardization (2009). Acoustics- Determination of occupational noise exposure- Engineering method. EN ISO 9612:2009, Switzerland

5. European Parliament and of the Council (2003). Directive 2003/10/CE on the minimum health and safety requirements regarding the exposure of workers to the risks arising from physical agents. Eurpean Union: Ed. European Parliament and of the Council

6. Normativ privind Protectia la Zgomot C125-2013, Editura Fastprint, Bucureşti, 2014

7. Tandel, B.N, \& Jem, M. (2013). Assessment and Mlr Modelling Of Urban Traffic Noises at Major Arterial Roads of Surat. Journal of Environmental Research and Development. 2013; 7(4A):17031709.

8. Méline, J., Van Hulst, A., Thomas, F., Karusisi, N \& Chaix, B. (2013). Transportation noise and annoyance related to road traffic in the French RECORD study. Int J Health Geogr. 2013;12:44.

9. Brambilla, G., Gallo. V, \& Zambon. G. (2013). The Soundscape quality in some urban parks in Milan, Italy. Int J Environ Res Public Health. 2013;10:2348-6

10. Iordache, V. \& Catalina, T. (2013). Experimental investigation on the sound pressure level for a high 
thermal capacity burner during a running cycle. JOURNAL Applied Acoustics, Volume: 74 Issue: 5 Pages: 708-717

11. Tacutu, L., Pocola, A., Balan, M. \& Iordache, V. (2017). Acoustic measurements for two configurations of acoustic casings with applications on ambient noise pollution, Conference: 8th International Conference on ENERGY and ENVIRONMENT (CIEM). 19-20 October 2017 (pp. 129-133). Bucharest, Romania: International Conference on Energy and Environment.

12. Malet T., Acoustique des salles - Le guide de référence du practicien,Publ. Georges Ventillard, Neuilly sur Marne, 2005;

13. Stan M., Acustica pentru arhitecti, Ed. Fundatiei Romania de Mâine, Bucuresti 2007.

14. Hamayon L., Réussir l'acoustique d'un batiment, Ed. Le Moniteur, Paris, 1996;

15. Pellerin G.,Acoustique architecturale: Theories et pratiques, version électronique, 2006;

16. Bratu P., Acustica interioară pentru construcţii şi maşini, Editura Matrix Rom, Bucureşti, 2002

17. Iordache V.,Catalina T., Acustica clădirii şi a instalatiilor- Aplicatii proiectare,, Editura Matrix Rom, Bucuresti, 2013

18. Iudin, E.Ia., Izolarea împotriva zgomotelor, Traducere din limba rusă, Ed. Tehnică, Bucureşti, 1968.

19. Enescu, N., Magheţi, I., Sârbu,M. A., Acustică tehnică, Ed. ICPE, București,'98, ISBN 973-988012-6.

20. Bell, L. H., Noise and Vibration Control. Fundamentals and Applications, Marcel Dekker, Inc. 1982

21. Bell, L.H., Bell, D.H., Industrial noise control. Fundamentals and applications. Second edition,revised and expanded, Ed. Marcel Dekker, Inc., 1994, ISBN 0-8247-9028-6.

22. Beranek, L.L., Vér, I.L., Noise and Vibration Control. Principles and Applications, John Wiley \&Sons, Inc., New York, 1992, ISBN 0-471-617512.

23. Selamet, A., Denia, F.D., Besa, A.J., Acoustic behavior of circular dual-chamber mufflers, Journal of

24. Sound and Vibration 265 (2003), 967-985.

25. Tao, Z., Herrin, D.W., Seybert, A.F., A Review of Current Techniques for Measuring Muffler Transmission Loss, 03NVC-38, 2001, Society of Automotive Engineers, Inc.

26. STAS 10009-88 - Acustica urbană. Limite admisibile ale nivelului de zgomot

27. STAS 6161/1-79 - Acustica in construcții. Partea 1: Măsurarea nivelului de zgomot în construcţii civile. Metode de masurare 